\title{
THE ROLE OF PARENTS IN BLENDED LEARNING TOWARDS STUDENT CHARACTER VALUES IN THE COVID-19 PANDEMIC
}

\author{
Yusnita Lestaria Simvony \\ Sekolah Tinggi Keguruan dan Ilmu Pendidikan (STKIP) PGRI Trenggalek \\ lestariayusnita46@gmail.com
}

Agus Budi Santosa

Sekolah Tinggi Keguruan dan Ilmu Pendidikan (STKIP) PGRI Trenggalek agus.budiku@gmail.com

\section{Wahyu Nugroho}

Sekolah Tinggi Keguruan dan Ilmu Pendidikan (STKIP) PGRI Trenggalek nugrohowahyu.wn93@gmail.com

\begin{abstract}
The Covid-19 pandemic hampers the cultivation of character values in students, therefore it is necessary for the role of parents in Blended Learning to instill character values. This research is a quantitative research with sampling technique using stratified proportional random sampling. The results of the Shapiro-Wilk normality test showed that the significance value of the parent's role was $0.157>0.05$. The significance value for the student character is $0.280>0.05$ so that the data is normally distributed. Test for linearity sig $0.305>0.05$ so that the variables $X$ and $Y$ are linear. The results of the hypothesis test are $0.000<0.05$, and the Pearson Correlation value is 0.600 , then $\mathrm{Ha}$ is accepted and $\mathrm{HO}$ is rejected. So it can be concluded that there is a strong relationship between the role of parents in blended learning and the cultivation of character values during the Covid-19 pandemic.
\end{abstract}

Keyword: Role of Parents, Blended Learning, Student Character Values.

\begin{abstract}
Abstrak
Masa pandemi Covid-19 ini menghambat proses pembelajaran serta penanaman nilai karakter pada siswa, oleh sebab itu perlu adanya peran orangtua dalam pembelajaran Blended Learning untuk menanamkan nilai karakter. Penelitian ini merupakan penelitian kuantitatif dengan teknik pengumpulan data menggunakan kuesioner dan wawancara. Teknik pengambilan sampel menggunakan stratified proportional random sampling. Uji validitas menggunakan uji ahli dan uji reliabilitas menggunakan uji Spearman Brown. Hasil uji normalitas Shapiro-Wilk menunjukkan nilai signifikansi peran orang tua sebesar 0,157 >0,05. Nilai signifikansi untuk karakter siswa adalah 0,280 > 0,05 sehingga data berdistribusi normal. Uji linieritas sig 0,305 > 0,05 sehingga variabel X dan Y linier. Hasil uji hipotesis 0,000 <0,05, dan nilai Pearson Correlation sebesar 0,600, maka Ha diterima dan HO ditolak. Sehingga dapat di simpulkan bahwa terdapat hubungan yang kuat antara peran orang tua dalam blended learning dengan penanaman nilai-nilai karakter di masa pandemi Covid-19.
\end{abstract}

Kata Kunci: Peran Orang Tua, Blended Learning, Nilai Karakter Siswa.

Program Studi Pendidikan Guru Madrasah Ibtidaiyah STAI Al-Azhar Menganti Gresik, Indonesia

Available online on: http://jurnal.stai-alazharmenganti.ac.id/index.php/ZAHRA 
ZAHRA: Research And Tought Elmentary School Of Islam Journal Vol. (2) (2), (Agustus)(2021), (Halaman)(134-143)| 135

Pendahuluan

Tujuan utama dari pendidikan adalah membentuk generasi bangsa yang memiliki karakter yang baik. Setiap siswa memiliki hak untuk memperoleh pelayanan maksimal dalam pendidikan sesuai tingkatannya (Nugroho,2021). Melalui sistem kurikulum 2013 saat ini telah menanamkan watak atau budi pekerti yang baik pada diri seseorang yang berkaitan dengan sikap, pikiran, perkataan, dan perbuatan. Penanaman nilai karakter di sekolah diharapkan mampu meningkatkan mutu pendidikan yang mengarah pada pembentukan karakter dan watak mulia peserta didik secara seimbang dan utuh sesuai dengan standar kompetensi lulusan serta terinternalisasi dan terwujud dalam perilaku kehidupan sehari-hari (Asmani, 2013:43).

Sekolah sebagai pendidikan formal menjadi tonggak dalam merencanakan dan melaksanakan pembelajaran yang mengandung internalisasi nilai-nilai karakter dalam kehidupan sehari-hari siswa. Sekolah memiliki peran dalam membimbing siswa menemukan nilai kebaikan dan kebenaran serta mengembangkan karakter siswa (Eken Res Assist student et al., 2019). Dalam hal ini, sekolah menjalankan perannya dengan cara mendesain dan melaksanakan pembelajaran yang mengintegrasikan pendidikan karakter di dalamnya serta melakukan penilaian sikap (afektif) siswa dalam pembelajaran. Indikator keberhasilan penanaman nilai karakter di sekolah ditandai dengan tertanamnya karakter baik dalam diri siswa yang diimplementasikan dalam perilaku sehari-hari.

Namun, pada kenyataannya penanaman nilai karakter siswa masih rendah. Hal ini terbukti dari banyaknya kasus yang menunjukkan rusaknya moral dikalangan pelajar. Salah satu peserta didik SMP swasta di Kabupaten Gresik menantang gurunya dengan cara menarik kerah baju gurunya saat diingatkan untuk tidak merokok (Purnomo, 2019). Tidak hanya di jenjang pendidikan SMP, kasus lain juga terjadi pada jenjang pendidikan SD. Kasus bullying terjadi di Kota Solo yang melibatkan delapan siswa SD. Pelaku melakukan perundungan kepada korban dengan cara menampar wajah dan mendorong korban (Sunaryo, 2020).

Rendahnya nilai karakter siswa di Indonesia tentunya menjadi problematika pendidikan di Indonesia. Dalam menghadapi permasalahan ini instansi pendidikan harus tanggap dalam mencari solusi dari permasalahan tersebut, khususnya dalam pembelajaran masa pandemi Covid-19 saat ini. Covid-19 merupakan virus yang menyerang saluran pernapasan dan dapat menyebabkan penyakit pnemunomia bahkan kematian (Handayani, dkk., 2020:122-123). Demi memutus penyebaran virus tersebut pemerintah Indonesia menghimbau kepada masyarakat Indonesia untuk beribadah dari rumah, bekerja dari rumah, 
ZAHRA: Research And Tought Elmentary School Of Islam Journal Vol. (2) (2), (Agustus)(2021), (Halaman)(134-143)| 136 dan belajar dari rumah. Himbauan tersebut disampaikan oleh Presiden Joko Widodo pada tanggal 15 Maret 2020 di Istana Kepresidenan Bogor (Rohida \& Fitriani, 2020: 30-31).

Kondisi ini membuat pendidikan di semua jenjang dilakukan secara jarak jauh. Pembelajaran Jarak Jauh (PJJ) atau daring pada pandemi saat ini tidak memungkinkan sekolah dapat mengoptimalkan perannya sebagai sarana penanaman nilai karakter bagi siswa. Guru hanya bertemu dengan siswa secara maya tanpa adanya interaksi langsung. Dalam pertemuannya guru membahas mengenai materi yang harus dikuasai siswa dan selebihnya adalah pemberian tugas yang dikumpulkan secara online. Hal ini menunjukkan bahwa interaksi antara guru dan siswa sangat terbatas.

Dari permasalahan di atas solusi yang dapat diambil yaitu mengoptimalkan peran orang tua dalam penanaman karakter peserta didik dalam blended learning. Berdasarkan hasil wawancara dan observasi di SDN 2 Sengon, sekolah sudah menerapkan langkah tersebut sebagai terobosan baru peningkatan mutu penyelenggaraan pendidikan dan peningkatan karakter peserta didik di masa pandemi. Dengan menerapkan blended learning pembelajaran lebih bervariasi dan tentunya juga dapat mengoptimalkan penanaman nilai karakter siswa. Pernyataan ini didukung oleh penelitian terdahulu yang dilakukan oleh Nurul Inayah pada Oktober 2019 dengan hasil penelitian menunjukkan bahwa blended learning mempengaruhi peningkatan karakter siswa dengan kategori peningkatan tinggi.

Orang tua sebagai orang terdekat dengan peserta didik sekaligus sebagai guru saat di rumah memiliki peran penting dalam menanamkan nilai karakter sebagai karakter dasar yang diperoleh peserta didik dari lingkungan keluarga. Orang tua memiliki peran penting dalam memberi contoh kebaikan kepada anak-anaknya (Ikhwan, dkk., 2019: 323-335). Hal ini juga didukung oleh penelitian terdahulu dengan judul "Peran Orang Tua Dan Peran Guru Terhadap Pendidikan Karakter" yang menyimpulkan bahwa hasil penelitian terdapat hubungan yang positif dan signifikan antara peran orang tua dengan karakter siswa. Hubungan tersebut bersifat kuat yaitu dengan nilai koefisien korelasi sebesar 0,789 (Aruan, dkk., 2021). Selain itu keberhasilan pembelajaran dengan blended learning telah terbukti memberikan kontribusi dalam menanamkan karakter kemandirian siswa, hal ini didukung oleh hasil penelitian terdahulu yang menyatakan bahwa dalam penerapan model pembelajaran blanded learning siswa lebih difasilitasi dalam meningkatkan potensi kemandirian belajar yang berpengaruh positif terhadap karakter siswa (Usman,2018). Berdasarkan fakta yang ada permasalahan dapat diselesaikan dengan mengoptimalkan peran orang tua dalam blended learning. Sehingga peneliti mengambil judul "Peran Orang tua 
ZAHRA: Research And Tought Elmentary School Of Islam Journal Vol. (2) (2), (Agustus)(2021), (Halaman)(134-143)| 137 dalam Blended Learning terhadap Penanaman Nilai Karakter siswa SDN 2 Sengon di Masa Pandemi Covid-19”

\section{Metode Penelitian}

Penelitian yang digunakan dalam penelitian ini adalah penelitian kuantitatif dengan pendekatan deskriptif. Pendekatan deskriptif digunakan untuk mendeskripsikan objek penelitian maupun hasil penelitian (Priyono, 2016:37). Adapaun sifat dari penelitian ini adalah penelitian korelasi dan metode yang digunakan adalah metode survei.

Populasi dan sampel pada penelitian ini adalah siswa kelas I-VI SDN 2 Sengon. Teknik sampel yang digunakan adalah stratified proporsional random sampling dengan jumlah sampel 48. Jenis angket atau kuisioner yang digunakan yaitu angket tertutup dengan jawaban yang menggambarkan diri responden sendiri (langsung) dengan bentuk rating scale (skala bertingkat) menggunakan skala likert. Angket digunakan untuk memperoleh data yang berkaitan dengan peran orang tua dan karakter siswa. Wawancara digunakan untuk mengumpulkan data mengenai pelaksaan blended learning di SDN 2 Sengon. Wawancara yang digunakan yaitu wawancara terstruktur.

Uji validitas dan uji reliabilitas pada penelitian ini menggunakan uji validitas ahli. uji normalitas data menggunakan uji Shapiro Wilk dengan bantuan SPSS 25, dengan ketentuan apabila nilai sig < 0,05 maka data berdistribusi tidak normal. Uji linearitas data dilakukan dengan batuan SPSS 25, dengan ketentuan yaitu apabila nilai sig dari nilai Deviation from Linearity > 0,05 maka dua variabel dikatakan memiliki hubungan linear. Selain itu, dengan membandingkan nilai $\mathrm{F}$ tabel dengan $\mathrm{F}$ hitung, dengan pengambilan keputusan yaitu nilai $\mathrm{F}$ hitug $<\mathrm{F}$ tabel maka maka dua variabel dikatakan memiliki hubungan linear. Pada uji hipotesis dilakukan dengan uji korelasi Product Moment Pearson dengan kriteria apabila diperoleh nilai Sig. $<0,025$ (2-tailed), maka Ho ditolak dan Ha diterima. Selain dilakukan uji hipotesis juga dilakukan perhitungan Koefien Determinasi untuk melihat seberapa besar konstribusi peran orang tua terhadap penanaman nilai karakter siswa dengan rumus $\mathrm{KD}=\mathrm{r}^{2} \mathrm{x} 100 \%$, dimana $\mathrm{r}$ merupakan $\mathrm{r}$ hitung.

\section{Hasil Penelitian}

Penelitian yang dilakukan dengan membagikan angket kepada siswa dan orang tua siswa diperoleh hasil penelitian sebagai berikut.

Tabel 1. Data Peran Orang tua dalam Penanaman Nilai Karakter Siswa

\begin{tabular}{cccc}
\hline $\begin{array}{c}\text { Nama } \\
\text { Sampel }\end{array}$ & Nilai & $\begin{array}{c}\text { Nama } \\
\text { Sampel }\end{array}$ & Nilai \\
\hline O1 & 70 & O25 & 76 \\
O2 & 73 & O26 & 57 \\
O3 & 66 & O27 & 67 \\
O4 & 70 & O28 & 76 \\
O5 & 73 & O29 & 76 \\
O6 & 67 & O30 & 69 \\
O7 & 60 & O31 & 75 \\
O8 & 62 & O32 & 68 \\
O9 & 64 & O33 & 66 \\
O10 & 70 & O34 & 62
\end{tabular}


ZAHRA: Research And Tought Elmentary School Of Islam Journal Vol. (2) (2), (Agustus)(2021), (Halaman)(134-143)| 138

\begin{tabular}{llll} 
O11 & 66 & O35 & 63 \\
O12 & 71 & O36 & 67 \\
O13 & 54 & O37 & 64 \\
O14 & 73 & O38 & 60 \\
O15 & 66 & O39 & 67 \\
O16 & 66 & O40 & 71 \\
O17 & 67 & O41 & 64 \\
O18 & 70 & O42 & 62 \\
O19 & 70 & O43 & 65 \\
O20 & 69 & O44 & 73 \\
O21 & 73 & O45 & 72 \\
O22 & 76 & O46 & 76 \\
O23 & 70 & O47 & 74 \\
O24 & 67 & O48 & 71 \\
\hline
\end{tabular}

Berdasarkan tabel 1 dapat diketahui data peran orang tua dalam penanaman nilai karakter siswa di SDN 2 Sengon. Jumlah sampel (n) adalah 48. Setiap sampel memiliki nilai peran yang berbeda-beda. Nilai tertinggi dari data tersebut adalah 76 dan nilai terendahnya adalah 54 .

Tabel 2. Data Karakter Siswa

\begin{tabular}{cccc}
\hline $\begin{array}{c}\text { Nama } \\
\text { Sampel }\end{array}$ & Nilai & $\begin{array}{c}\text { Nama } \\
\text { Sampel }\end{array}$ & Nilai \\
\hline S1 & 151 & S25 & 158 \\
S2 & 174 & S26 & 121 \\
S3 & 130 & S27 & 147 \\
S4 & 145 & S28 & 148 \\
S5 & 174 & S29 & 176 \\
S6 & 136 & S30 & 163 \\
S7 & 146 & S31 & 154 \\
S8 & 134 & S32 & 139 \\
S9 & 134 & S33 & 165 \\
S10 & 161 & S34 & 157 \\
S11 & 145 & S35 & 156 \\
S12 & 157 & S36 & 149 \\
S13 & 111 & S37 & 143 \\
S14 & 159 & S38 & 141 \\
S15 & 164 & S39 & 156 \\
S16 & 154 & S40 & 157 \\
S17 & 145 & S41 & 134 \\
S18 & 156 & S42 & 163 \\
S19 & 155 & S43 & 168 \\
S20 & 154 & S44 & 153 \\
S21 & 143 & S45 & 166 \\
S22 & 145 & S46 & 176 \\
S23 & 156 & S47 & 166 \\
S24 & 134 & S48 & 165 \\
\hline
\end{tabular}

Berdasarkan tabel 2 di atas, menyajikan data karakter siswa. Jumlah sampel (n) data di atas adalah 48. Setiap siswa memiliki nilai karakter berbeda-beda. Nilai tertinggi yang diperoleh adalah 176 dan nilai terendahnya adalah 111 .

Adapun penelitian terdahulu yang relevan dengan penelitian yang dilakukan oleh peneliti adalah sebagai berikut:

Tabel 3 Penelitian yang Relevan

\begin{tabular}{|c|c|c|c|c|}
\hline Nama Peneliti & Tahun & Judul & Hasil & $\begin{array}{c}\text { Perbedaan dan } \\
\text { Persamaan } \\
\end{array}$ \\
\hline Nurul Inayah & 2019 & Keefektifan & Hasil penelitian & Perbedaan: \\
\hline
\end{tabular}




\begin{tabular}{|c|c|c|c|c|}
\hline Nama Peneliti & Tahun & Judul & Hasil & $\begin{array}{l}\text { Perbedaan dan } \\
\text { Persamaan }\end{array}$ \\
\hline $\begin{array}{l}\text { dari Program } \\
\text { Studi } \\
\text { Pendidikan } \\
\text { Kimia Pasca } \\
\text { Sarjana } \\
\text { Universitas } \\
\text { Negeri } \\
\text { Semarang }\end{array}$ & & $\begin{array}{l}\text { metode blended } \\
\text { learning berbasis } \\
\text { multimedia untuk } \\
\text { analisis } \\
\text { pemahaman } \\
\text { konsep dan } \\
\text { pengembangan } \\
\text { karakter peserta } \\
\text { didik pada materi } \\
\text { senyawa } \\
\text { hidrokarbon }\end{array}$ & $\begin{array}{l}\text { yang diperoleh } \\
\text { yaitu penerapan } \\
\text { pembelajaran } \\
\text { blended learning } \\
\text { mempengaruhi } \\
\text { peningkatan } \\
\text { karakter siswa } \\
\text { dengan kategori } \\
\text { peningkatan } \\
\text { tinggi. }\end{array}$ & $\begin{array}{l}\text { Pada penelitian yang } \\
\text { dilakukan oleh Nurul } \\
\text { Inayah penerapan } \\
\text { blended learning } \\
\text { diterapkan pada satu } \\
\text { mata pelajaran tertentu } \\
\text { yaitu mata pelajaran } \\
\text { IPA materi senyawa } \\
\text { hidrokarbon sedangkan } \\
\text { pada penelitian ini } \\
\text { blended learning } \\
\text { dilakukan pada semua } \\
\text { mata pelajaran. Selain } \\
\text { itu, pada penelitian } \\
\text { terdahulu blended } \\
\text { learning dilakukan oleh } \\
\text { peneliti sedangkan pada } \\
\text { penelitian ini blended } \\
\text { learning dilakukan oleh } \\
\text { guru. } \\
\text { Persamaan: } \\
\text { Tujuannya sama-sama } \\
\text { untuk meningkatkan } \\
\text { karakter siswa. }\end{array}$ \\
\hline $\begin{array}{lr}\text { Sri } & \text { Sumartini } \\
\text { dari } & \text { Fakultas } \\
\text { Ilmu } & \text { Tarbiyah } \\
\text { Dan } & \text { keguruan } \\
\text { UIN } & \text { Sunan } \\
\text { Kalijaga } & \end{array}$ & 2019 & $\begin{array}{l}\text { Pengaruh Peran } \\
\text { Guru dan Pola } \\
\text { Asuh Orang tua } \\
\text { terhadap } \\
\text { Pembentukan } \\
\text { Karakter Siswa di } \\
\text { MIN 2 Sleman }\end{array}$ & $\begin{array}{l}\text { Pola asuh orang } \\
\text { tua memberikan } \\
\text { pengaruh positif } \\
\text { signifikan } \\
\text { terhadap } \\
\text { pembentukan } \\
\text { karakter siswa } \\
\text { MIN } 2 \text { Sleman }\end{array}$ & $\begin{array}{l}\text { Perbedaan: } \\
\text { Pada } \\
\text { terdahulu denelitian } \\
\text { pada peran orang tua } \\
\text { dalam menanamkan } \\
\text { nilai kaakter melalui } \\
\text { pola asuh orang tua } \\
\text { sedangkan pada } \\
\text { penelitian } \\
\text { difokuskan pada peran } \\
\text { orang tua pada } \\
\text { penanaman } \\
\text { karakter siswa yaitu } \\
\text { meliputi menjadi role } \\
\text { model, membiasakan } \\
\text { hal baik pada anak, } \\
\text { melakukan dialog dan } \\
\text { diskusi, memberikan } \\
\text { sanksi } \\
\text { Persamaan: } \\
\text { Sama-sama meneliti } \\
\text { peran orang tua dalam } \\
\text { menanamkan nilai } \\
\text { karakter kepada anak. }\end{array}$ \\
\hline $\begin{array}{lr}\text { Yusnita Aruan, } \\
\text { dkk dari } \\
\text { Universitas } \\
\text { Kristen } \\
\text { Indonesia }\end{array}$ & 2021 & $\begin{array}{l}\text { Peran orang tua } \\
\text { dan peran guru } \\
\text { terhadap } \\
\text { pendidikan } \\
\text { karakter }\end{array}$ & $\begin{array}{l}\text { Hubungan peran } \\
\text { orang tua dengan } \\
\text { pendidikan } \\
\text { karakter siswa } \\
\text { berkorelasi kuat }\end{array}$ & $\begin{array}{lr}\text { Perbedaan: } & \\
\text { Penelitian } & \text { terdahulu } \\
\text { dilakukan } & \text { untuk } \\
\text { meneliti } & \text { hubungan } \\
\text { orang tua } & \text { dengan } \\
\text { pendidikan } & \text { karakter } \\
\text { bersamaan } & \text { dengan } \\
\text { meneliti } & \text { hubungan } \\
\text { peran guru dengan } \\
\text { pendidikan } & \text { karakter. }\end{array}$ \\
\hline
\end{tabular}




\begin{tabular}{|c|c|c|c|c|}
\hline Nama Peneliti & Tahun & Judul & Hasil & $\begin{array}{c}\text { Perbedaan dan } \\
\text { Persamaan }\end{array}$ \\
\hline & & & & $\begin{array}{l}\text { sedangkan pada } \\
\text { penelitian ini peran } \\
\text { orang tua yang diteliti } \\
\text { yaitu peran orang tua } \\
\text { dalam penanaman nilai } \\
\text { karakter siswa yang } \\
\text { dilaksanakan dalam } \\
\text { blended learning. } \\
\text { Persamaan: } \\
\text { Sama-sama meneliti } \\
\text { hubungan peran orang } \\
\text { tua dengan penanaman } \\
\text { nilai karakter siswa. }\end{array}$ \\
\hline
\end{tabular}

Berdasarkan tabel diatas dapat disimpulkan bahwa perbedaan penelitian ini dengan penelitian terdahulu adalah pada penelitian ini dilakukan untuk mencari hubungan antara peran orang tua dalam blended learning terhadap penanaman nilai karakter siswa. Blended learning pada penelitian ini dilakukan oleh guru dan pelaksanaan blended learning digunakan untuk memperkuat peran orang tua dalam penanaman nilai karakter siswa.

Hasil penelitian ini terdapat hubungan yang kuat antara peran orang tua dalam blended learning dengan penanaman nilai karakter siswa SDN 2 Sengon Kecamatan Bendungan di masa pandemi Covid-19 dengan nilai koefisien korelasi 0,600. Penelitian sebelumnya yang dilakukan oleh Yusnita Aruan pada tahun 2021 dengan judul "Peran Orang Tua Dan Peran Guru Terhadap Pendidikan Karakter" juga terdapat hubungan yang positif dan signifikan antara peran orang tua dengan karakter siswa. Hubungan tersebut bersifat kuat yaitu dengan nilai koefisien korelasi sebesar 0,789 .

Penelitian ini peran orang tua memberikan sumbangan sebesar 36\% terhadap penanaman nilai karakter siswa. Hal ini menunjukkan bahwa tidak hanya orang tua yang berperan dalam penanaman nilai karakter siswa, melainkan ada pihak atau faktor lain. Berdasarkan penelitian yang dilakukan oleh Sri Sumartini pada tahun 2019 dengan judul "Pengaruh Peran Guru dan Pola Asuh Orang tua terhadap Pembentukan Karakter Siswa di MIN 2 Sleman" diketahui bahwa peran orang tua memberikan sumbangan sebesar 25\% terhadap penanaman nilai karakter siswa. Selebihnya ada faktor lain yang berperan dalam pembentukan karakter siswa. Berdasarkan penelitian yang dilakukan oleh Suparno pada tahun 2018 dengan judul penelitian "Analisis Faktor-Faktor Pembentuk Karakter SMART Siswa di Sekolah Islam Terpadu", adapun faktor-faktor yang mempengaruhi penanaman nilai karakter siswa adalah lingkungan sosial, lingkungan belajar, dan interaksi teman sebaya.

\section{Diskusi}

Data yang telah diperoleh dari angket kemudian dilakukan analisis data yaitu uji normalitas, uji linearitas, dan uji hipotesis. Langkah pertama yang dilakukan adalah melakukan uji normalitas data. Berikut adalah uji normalitas data penelitian yang disajikan dalam bentuk tabel. 
ZAHRA: Research And Tought Elmentary School Of Islam Journal Vol. (2) (2), (Agustus)(2021), (Halaman)(134-143)| 141

Tabel 4. Output Hasil Uji Normalitas

\begin{tabular}{|c|c|c|c|c|c|c|c|}
\hline \multicolumn{8}{|c|}{ Tests of Normality } \\
\hline \multirow{2}{*}{\multicolumn{2}{|c|}{ Kelompok }} & \multicolumn{3}{|c|}{ Kolmogorov-Smirnov ${ }^{a}$} & \multicolumn{3}{|c|}{ Shapiro-Wilk } \\
\hline & & Statistic & $D f$ & Sig. & Statistic & $d f$ & Sig. \\
\hline \multirow[t]{2}{*}{$\begin{array}{l}\text { Nilai } \\
\text { Angket }\end{array}$} & $\begin{array}{l}\text { Peran } \\
\text { Orang tua }\end{array}$ & 0,094 & 48 & $0,200^{*}$ & 0,965 & 48 & 0,157 \\
\hline & $\begin{array}{l}\text { Karakter } \\
\text { Siswa }\end{array}$ & 0,105 & 48 & $0,200^{*}$ & 0,971 & 48 & 0,280 \\
\hline
\end{tabular}

Berdasarkan tabel 3 di atas, diperoleh nilai signifikansi untuk masing-masing data. Nilai signifikansi dapat dilihat pada tabel Shapiro Wilk. Nilai Sig. angket peran orang tua adalah 0,157 > 0,05 . Nilai Sig. angket karakter siswa adalah $0,280>0,05$. Sehingga dapat disimpulkan bahwa data peran orang tua dan karakter siswa berdistribusi normal.

Setelah dilakukan uji normalitas selanjutnya data penelitian dilakukan uji linearitas, dengan hasil sebagai berikut:

Tabel 5. Output Hasil Uji Linearitas

\begin{tabular}{|c|c|c|c|c|c|c|c|}
\hline \multicolumn{8}{|c|}{ ANOVA Table } \\
\hline \multirow{6}{*}{$\begin{array}{l}\text { Karakter } \\
\text { Siswa * } \\
\text { Peran } \\
\text { Orang tua } \\
\text { dalam } \\
\text { Penanaman } \\
\text { Nilai } \\
\text { Karakter }\end{array}$} & \multirow{4}{*}{$\begin{array}{l}\text { Betwee } \\
n \\
\text { Groups }\end{array}$} & \multirow[b]{2}{*}{$\begin{array}{l}\text { (Combin } \\
\text { ed) }\end{array}$} & $\begin{array}{l}\text { Sum of } \\
\text { Squares }\end{array}$ & $d f$ & $\begin{array}{l}\text { Mean } \\
\text { Square }\end{array}$ & $F$ & Sig. \\
\hline & & & 5659,567 & 17 & 332,92 & 2,8 & 0,007 \\
\hline & & Linearity & 3326,19 & 1 & 3326,2 & 28 & 0 \\
\hline & & $\begin{array}{l}\text { Deviatio } \\
n \text { from } \\
\text { Linearity }\end{array}$ & 2333,376 & 16 & 145,84 & 1,2 & 0,305 \\
\hline & Within & oups & 3569,433 & 30 & 118,98 & & \\
\hline & Total & & 9229 & 47 & & & \\
\hline
\end{tabular}

Berdasarkan tabel di atas, diperoleh nilai signifikansi Deviation from Linearity sebesar 0,305 $>0,05$ dan nilai $F$ hitung sebesar 1,226. Nilai $F$ tabel yang diperoleh dengan melihat nilai df $(16,30)$ adalah sebesar 1,99. Sehingga nilai $F$ hitung $<F$ tabel yaitu 1,226 < 1,99. Jadi, dapat disimpulkan bahwa data antara variabel peran orang tua dan penanaman nilai karakter siswa bersifat linear.

Berdasarkan uraian di atas data penelitian berdistribusi normal dan bersifat linear. Selanjutnya, data penelitian dilakukan uji hipotesis. Uji hipotesis dilakukan dengan uji korelasi Product Moment Pearson. Korelasi Product Moment Pearson memiliki inteprestasi nilai koefisien korelasi adalah sebagai berikut:

Tabel 6. Interpretasi Koefisien Korelasi

\begin{tabular}{ccc}
\hline No & $\begin{array}{c}\text { Interval } \\
\text { Koefisien }\end{array}$ & $\begin{array}{c}\text { Tingkat } \\
\text { Hubungan }\end{array}$ \\
\hline 1 & $0,00-0,199$ & Sangat rendah \\
2 & $0,20-0,399$ & Rendah \\
3 & $0,40-0,599$ & Sedang \\
4 & $0,60-0,799$ & Kuat \\
5 & $0,80-1,000$ & Sangat kuat \\
\hline
\end{tabular}

Berikut adalah hasil uji hipotesis data penelitian menggunakan uji korelasi Product Moment Pearson. 


\begin{tabular}{|c|c|c|c|}
\hline \multicolumn{4}{|c|}{ Correlations } \\
\hline & & $\begin{array}{c}\text { Peran Orang tua } \\
\text { dalam Penanaman } \\
\text { Nilai Karakter }\end{array}$ & Karakter Siswa \\
\hline $\begin{array}{l}\text { Peran Orang tua } \\
\text { dalam }\end{array}$ & $\begin{array}{l}\text { Pearson Correlation } \\
\text { Sig. (2-tailed) }\end{array}$ & 1 & $\begin{array}{r}0,600^{* *} \\
0,000\end{array}$ \\
\hline $\begin{array}{l}\text { Penanaman } \\
\text { Nilai Karakter }\end{array}$ & $\mathrm{N}$ & 48 & 48 \\
\hline Karakter Siswa & $\begin{array}{l}\text { Pearson Correlation } \\
\text { Sig. (2-tailed) }\end{array}$ & $\begin{array}{r}0,600^{* *} \\
0,000\end{array}$ & 1 \\
\hline **. Correlation i & significant at the 0.0 & -tailed). & 48 \\
\hline
\end{tabular}

Berdasarkan tabel 7 diperoleh nilai Sig. sebesar 0,000 < 0,025 (2-tailed) maka Ho ditolak dan Ha diterima. Dalam tabel juga diperoleh nilai Pearson Correlation ( $\mathrm{r}$ hitung) sebesar 0,600 yang berarti tingkat hubungan kedua variabel adalah kuat. Sehingga, dapat disimpulkan bahwa terdapat hubungan antara peran orang tua dalam blended learning terhadap penanaman nilai karakter siswa SDN 2 Sengon di masa pandemi Covid-19. Selanjutnya, yaitu menghitung koefisien determinasi. Koefisien determinasi digunakan untuk mengetahui seberapa besar sumbangan peran orang tua mempengaruhi penanaman nilai karakter siswa. Rumus perhitungan koefisien determinasi adalah $\mathrm{r}^{2} \mathrm{x}$ $100 \%$ dimana $\mathrm{r}$ merupakan $\mathrm{r}$ hitung atau nilai Pearson Correlation Koefisien Determinasi $=36 \%$ artinya bahwa peran orang tua memberikan sumbangan sebesar $36 \%$ terhadap penananaman nilai karakter siswa di SDN 2 Sengon dalam blended learning selama pandemi Covid-19.

Diskusi hasil pembahasan peneliti ingin memberikan perbandingan data dari hasil penelitian sebelumnya yakni penelitian yang di lakukan oleh Yusnita Aruan yang mendeskripsikan bahwa dari hasil penelitian terdapat pengaruh positif dan signifikan antara peran orangtua dengan pendidikan karakter siswa, peran guru dengan pendidikan karakter siswa, serta terdapat pengaruh yang positif dan signifikan antara peran guru terhadap pendidikan karakter siswa jika peran orang tua dikendalikan. Adapun data yang diperoleh Koefisien Korelasi diperoleh sebesar 0,847 dengan signifikansi 0,000. Sementara, persamaan regresi adalah $\mathrm{Y}=0,560+0,863 \mathrm{X} 2$.

\section{Simpulan}

Berdasarkan diskusi dari keseluruhan simpulan dari pembahasan terdapat hubungan yang kuat antara peran orang tua dalam blended learning terhadap penanaman nilai karakter siswa SDN 2 Sengon di masa pandemi Covid-19. Hal ini diketahui koefisien korelasi dari nilai Pearson Correlation sebesar 0,600 yang menunjukkan tingkat korelasi kuat. Selain itu, peran orang tua memberikan sumbangan sebesar 36\% terhadap penanaman nilai karakter siswa SDN 2 Sengon dalam blended learning selama pandemi Covid-19.

\section{Daftar Pustaka}

Aruan, Yusnita, dkk. 2021. Peran Orang Tua dan Guru Terhadap Pendidikan Karakter. Jurnal IKRAITH Humaniora, 5 (1), 214-224. Retrieved from https://journals.upiyai.ac.id/index.php/ikraith-humaniora/article/view/945. 
ZAHRA: Research And Tought Elmentary School Of Islam Journal Vol. (2) (2), (Agustus)(2021), (Halaman)(134-143)| 143

Asmani, J.M. (2013). Buku Panduan Internalisasi Pendidikan Karakter di Sekolah. Cetakan ke-5. Jogjakarta: Diva Pers.

Eken Res Assist student, M., Yolcu Candidate, O., Çırakoğlu, M., \& of Atakent Erdogan Kibarer, P. (2019). Teachers' Views on Character/Values Education in Schools. International Journal of Psycho-Educational Sciences $\quad$ |, $\quad 8(3), \quad$ 14-28. https://www.journals.lapub.co.uk/index.php/IJPES.

Firiani, Y., \& Rohida, P. (2020). Analisa Pemanfaatan Teknologi Informasi dalam Pembelajaran Jarak Jauh di Tengah Pandemi Virus Corona Covid-19. Journal of Information System, Applied, Management, Accounting and Research. 4 (2): 30-36. Retrieved from http://journal.stmikjayakarta.ac.id/index.php/jisamar/article/view/181.

Handayani, D., dkk. (2020). Penyakit Virus Corona 2019. Jurnal Respirologi Indonesia, 40 (2): 119 129. https://doi.org/10.36497/jri.v40i2.101.

Ikhwan. A, dkk. (2019). Peran Keluarga dalam Internalisasi Nilai-Nilai Islam. Jurnal Dinamika Ilmu, (Online), 19 (2): 323-335. http://doi.org/10.21093/div.19i2.1746.

Inayah, N. (2020). Keefektifan Metode Blended Learning Multimedia Untuk Analisis Pemahaman Konsep dan Pemngembangan Karakter Peserta didik pada Materi Senyawa Hidrokarbon. Semarang: Unversitas Negeri Semarang. Retrieved from https://lib.unnes.ac.id/35097/.

Nugroho, W. (2021). Problematika Pemenuhan Hak Belajar Anak di Era Pandemi dari Sudut Pandang Guru, Siswa, dan Orangtua. In Implementasi dan Problematika Merdeka Belajar (pp. 199-206). Akademia Pustaka.

Priyono. 2016. Metode Penelitian Kuantitatif. Surabaya: Zifatama Publishing.

Purnomo, D. (2019). Murid Menentang Guru Bukti Gagalnya Pendidikan Karakter. (Online), https://www.kompasiana.com/donypurnomo/5c610caebde575270b7c8535/muridmenantang-guru-bukti-gagalnya-pendidikan-karakter, diakses 23 Desember 2020.

Sugiyono. (2019). Metode Penelitian Kuantitatif. Bandung: Penerbit Alfabeta.

Sumartini, S. (2019). Pengaruh Peran Guru dan Pola Asuh Orangtua Terhadap Pembentukan Karakter Siswa di MIN 2 Sleman (Tesis Magister yang tidak dipublikasikan). Universitas Islam Negeri Sunan Kalijaga, Yogyakarta.

Sunaryo, A. (2020). Pelaku Bullying Anak Sekolah Dasar di Solo. (Online), https://www.merdeka.com/peristiwa/polisi-sebut-pelaku-bullying-di-solo-diduga-8-anaksekolah-dasar.html, diakses 20 Januari 2021.

Usman. (2018). Komunikasi Pendidikan Berbasis Blended Learning dalam Membentuk Kemandirian Belajar. Jurnalisa, 4 (1): 136-150. https://doi.org/10.24252/jurnalisa.v4i1.5626. 